\title{
KAJIAN KARAKTERISTIK SENSORI DAN KAPASITAS ANTIOKSIDAN MINUMAN FUNGSIONAL BEKATUL BERAS HITAM DENGAN PENAMBAHAN JAHE (Zingiber officinale) DAN KENCUR (Kamferia galanga L.)
}

\author{
STUDY OF SENSORY CHARACTERISTICS AND ANTIOXIDANT CAPACITY \\ FUNCTIONAL DRINK BLACK RICE BRAN ADDITION OF GINGER (Zingiber Officinale) \\ AND GALINGALE (Kamferia Galanga L.)
}

\author{
Basito $^{1)}$ \\ ${ }^{1)}$ Staf Pengajar Program Studi ilmu dan Teknologi Pangan Fakultas Pertanian Universitas Sebelas Maret
}

\section{ABSTRACT}

Black rice bran is a source of natural antioxidants are cheap and easily obtainable. Black rice bran can be used as a functional beverage with added ingredients that taste flavor of ginger (Zingiber officinale) and galingale (Kamferia galanga L.). Ginger and galingale nutritionally complete enough for health. Ginger and galingale have a distinctive and strong flavor that is expected to close "langu" flavor of black rice bran. Black rice bran functional drink is expected to be used as an alternative functional drink. This study aimed to know the sensory characteristics of black rice bran functional drinks with the addition of ginger (Zingiber officinale) and galingale (Kamferia galanga L.) from various of formulations, to know the antioxidant capacity of total phenols, total anthocyanins and antioxidant activity of black rice bran functional drinks with the addition of ginger (Zingiber officinale) and galingale (Kamferia galanga L.) of the various formulations that were preferred. The study used Completely Randomized Design (CRD) with consisting of three factors, namely black rice bran, ginger and galingale with variations in the formulations used. Sensory characteristics of the test results showed that the panelists preferred to drink with the formula (bran: ginger: galingale) 70:15:15 and 70:20:10 of all formulations. In the formulations 70:15:15 indicate total phenol content of $705.99 \mathrm{mg} / 100 \mathrm{ml}$, total anthocyanin content of $133.97 \mathrm{mg} / 100 \mathrm{ml}$, and antioxidant activity content 54,36\%. While the formula 70:20:10 of total phenol content of $654.18 \mathrm{mg} / 100 \mathrm{ml}$, total anthocyanin content of $118.23 \mathrm{mg} / 100 \mathrm{ml}$, and antioxidant activity content $41.81 \%$.

Keywords: antioxidant capacity, black rice bran, galingale, ginger, sensory characteristics

\section{ABSTRAK}

Bekatul beras hitam merupakan sumber antioksidan alami yang murah dan mudah didapat. Bekatul beras hitam dapat dimanfaatkan sebagai minuman fungsional dengan menambahkan bahan pencita rasa yaitu dari jahe (Zingiber officinale) dan kencur (Kamferia galanga L.). Jahe dan kencur mengandung nutrisi yang cukup lengkap untuk kesehatan. Jahe dan kencur mempunyai flavor yang khas dan kuat yang diharapkan mampu menutup flavor langu dari bekatul beras hitam. Minuman fungsional bekatul beras hitam ini diharapkan dapat dijadikan sebagai alternatif minuman fungsional. Penelitian ini bertujuan untuk mengetahui karakteristik sensori minuman fungsional bekatul beras hitam dengan penambahan jahe (Zingiber officinale) dan kencur (Kamferia galanga L.) berbagai formulasi, menentukan kapasitas antioksidan yaitu total fenol, total antosianin dan aktivitas antioksidan minuman fungsional bekatul beras hitam dengan penambahan jahe (Zingiber officinale) dan kencur (Kamferia galanga L.) dari berbagai formulasi yang disukai. Rancangan penelitian ini menggunakan Rancangan Acak Lengkap (RAL) yang terdiri dari 3 faktor yaitu bekatul beras hitam, jahe dan kencur dengan variasi formulasi yang digunakan. Hasil uji karakteristik sensoris menunjukkan bahwa yang disukai panelis adalah minuman dengan formula (bekatul : jahe : kencur) 70:15:15 dan 70:20:10 dari semua formulasi. Pada formula 70:15:15 menunjukkan kadar total fenol sebesar 705,99 mg/100ml, kadar total antosianin sebesar 133,97 $\mathrm{mg} / 100 \mathrm{ml}$ dan aktivitas antioksidan sebesar 54,36\%. Sedangkan formula 70:20:10 kadar total fenolnya sebesar $654,18 \mathrm{mg} / 100 \mathrm{ml}$, kadar total antosianin $118,23 \mathrm{mg} / 100 \mathrm{ml}$ dan aktivitas antioksidan sebesar 41,81\%.

Kata Kunci : bekatul beras hitam, jahe, kapasitas antioksidan, karakteristik sensori, kencur

\section{PENDAHULUAN}

Sekarang ini banyak timbul berbagai penyakit degeneratif seperti kanker, hipertensi dan diabetes militus. Kesadaran masyarakat akan pentingnya pola hidup sehat dewasa ini semakin meningkat. Hal ini menyebabkan perubahan pola perilaku konsumen ke arah yang lebih baik terutama dalam memilih bahan pangan. Makanan/minuman yang dapat memenuhi fungsi mengatur metabolisme tubuh secara biologis disebut sebagai makanan/minuman fungsional.

Menurut Ardiansyah, (2009) dalam Auliana, Rizqie dkk. (2009) Fungsi fisiologis yang diharapkan dari makanan/minuman fungsional adalah pencegahan timbulnya 
penyakit, meningkatkan daya tahan tubuh, regulasi kondisi ritmik tubuh, memperlambat proses penuaan, dan penyehatan kembali. Oleh Kiswanto,2008 diterangkan bahwa minuman fungsional yang selama ini ada banyak dipasarkan, memanfaatkan buahbuahan, maupun sari kacang-kacangan. Namun pengembangan produk minuman fungsional dari bekatul beras hitam masih belum banyak dilakukan, hal ini merupakan upaya penting untuk mengurangi kecenderungan masyarakat mengkonsumsi soft drink, sekaligus memanfaatkan khasiat dari bekatul beras hitam untuk menjaga dan memelihara kesehatan.

Bekatul mengandung karbohidrat cukup tinggi, yaitu 51-55 g/100 g. Bekatul beras juga kaya akan vitamin B kompleks dan vitamin E. Vitamin B kompleks sangat dibutuhkan sebagai komponen pembangun tubuh, sedangkan vitamin E merupakan antioksidan yang sangat kuat yang bermanfaat dalam berbagai pencegahan penyakit termasuk penuaan dini. Bekatul juga merupakan sumber serat pangan (dietary fibre) yang sangat baik yaitu (25-35\%). Bekatul juga mengandung lemak tidak jenuh tinggi, lemak ini lebih aman dalam kaitannya dengan kolesterol sehingga aman dikonsumsi oleh penderita kolesterol dan penyakit jantung.

Potensi bekatul sebagai makanan bergizi telah banyak diteliti, namun pemanfaatan dan pengembangannya sebagai minuman yang layak belum banyak dilakukan, karena bekatul memiliki kelemahan mudah rusak oleh aktivitas hidrolitik dan oksidatif enzim lipase yang berasal dari dalam bekatul (endogenous) maupun aktivitas mikroba sehingga merusak senyawa bioaktif. Hidrolisis lipid dalam bekatul dapat muncul dalam berbagai bentuk, yaitu off flavor (seperti citarasa bersabun), meningkatnya keasaman, menurunya $\mathrm{pH}$, berubahnya karakter fungsional, dan meningkatnya kerentanan asam lemak terhadap oksidasi. Asam lemak bebas akan mengalami dekomposisi lanjutan (ketengikan) menghasilkan radikal bebas, citarasa buruk, dan hilangnya nilai gizi (Barnes dan Galliard, 1991 dalam Astawan, 2010).
Metode yang dapat digunakan untuk menghambat kerusakan bekatul adalah perlakuan fisik, mekanis, atau kombinasi keduanya, misalnya pembuatan bekatul menjadi makanan/minuman lain yang lebih awet merupakan salah satu cara mempertahankan senyawa bioaktif yang bermanfaat bagi kesehatan (Auliana, 2011).

Melihat prospek manfaat yang besar dan kemudahan mendapatkan bahan bakunya, bekatul dapat dioptimalkan penggunaanya sebagai minuman fungsional. Untuk mendapatkan citarasa yang lebih baik dan kesinergisan senyawa antioksidan diperlukan penambahan rempah-rempah. Rempah-rempah yang memiliki kandungan senyawa antioksidan dan diharapkan meningkatkan cita-rasa diantaranya jahe dan kencur. Kedua jenis rempah tersebut mudah diperoleh dan juga cukup terjangkau.

Jahe (Zingiber officinale), menurut Wijaya, 2002, merupakan tanaman yang sangat populer sebagai rempah-rempah dan bahan obat. Rimpang jahe juga memiliki banyak khasiat kesehatan, antara lain sebagai peluruh kentut (carminative), perangsang (stimulant), pemberi aroma atau bumbu, melancarkan sirkulasi darah, menurunkan kolesterol, tekanan darah, peluruh keringat (diaphoretic), antimuntah (antitussive), antiradang (anti-inflamantory) dan menambah nafsu makan.

Kencur (Kamferia galanga L) adalah salah satu jenis empon-empon yang banyak dimanfaatkan oleh rumah tangga dan industri obat maupun makanan serta minuman dan industri rokok kretek yang memiliki prospek pasar cukup baik. Secara empirik kencur digunakan sebagai penambah nafsu makan, ekspektoran, obat batuk, disentri, tonikum, infeksi bakteri, masuk angin, dan sakit perut (Rostiana dkk., 2007). Menurut Rukmana (1994) rimpang kencur mengandung saponin, flavonoid dan senyawa-senyawa polifenol, di samping minyak atsiri $(2,4-3,9 \%)$ yang mengandung sineol, borneol, kamfer, etil alkohol, dan senyawa-senyawa turunan asam sinamat. Minyak di dalam rimpang kencur mengandung etil sinnamat dan metil pmetoksi sisinamat yang banyak digunakan di dalam industri kosmetika dan dimanfaatkan sebagai obat asma dan anti jamur. 
Berdasarkan uraian di atas mengenai arti penting bekatul, jahe, dan kencur dirasa perlu dilakukan pengkajian tentang pembuatan minuman fungsional yang berbahan bakubekatul, jahe dan kencur ditinjau dari karakteristik sifat sensori dan fungsional (kapasitas antioksidan, total fenol, dan antosianin) yang disukai konsumen serta memiliki manfaat fungsional bagi kesehatan manusia.

\section{METODE PENELITIAN}

\section{Bahan}

a. Bahan utam: bekatul beras hitam jahe, kencur dan aquades.

b. Bahan untuk analisis karakteristik Fisikokimia adalah sebagai berikut : Aquades, reagen folin Ciocalteau Phenol, $\mathrm{Na}_{2} \mathrm{CO}_{3}$ jenuh, kertas saring, $\mathrm{HCL}, \mathrm{KCL}$, potassium asetat, 2,2-diphenyl-1picrylhydrazyl (DPPH) dan etanol.

Alat

Alat yang digunakan adalah timbangan, blender, kain saring, saringan, pemanas, panci, alat-alat gelas: spektrofotometer, tabung reaksi, gelas ukur, vortex, pipet volume, labu takar, propipet, pipet ukur dan seperangkat alat uji sensori.

\section{Tahapan Penelitian}

Tahapan dalam penelitian ini dinyatakan pada Gambar 1.

\section{Perancangan Penelitian dan Analisis Data}

Rancangan percobaan yang digunakan adalah Rancangan Acak Lengkap (RAL) pola faktorial yang terdiri dari 3 faktor yaitu bekatul beras hitam, jahe dan kencur dengan variasi formulasi yang digunakan (Tabel 1). Dari data yang diperoleh, dilakukan analisis secara ANOVA, untuk mengetahui ada tidaknya perbedaan perlakuan pada tingkat signifikan $\alpha=5 \%$. Kemudian dilanjutkan dengan DMRT pada tingkat $\alpha$ yang sama.

\section{Metode Analisis}

Minuman bekatul yang disukai dilakukan analisis Total Fenol, Total Antosianin, Aktivitas Antioksidan, serta Uji
Sensori. Masing-masing metode analisis dapat dilihat pada Tabel 2.

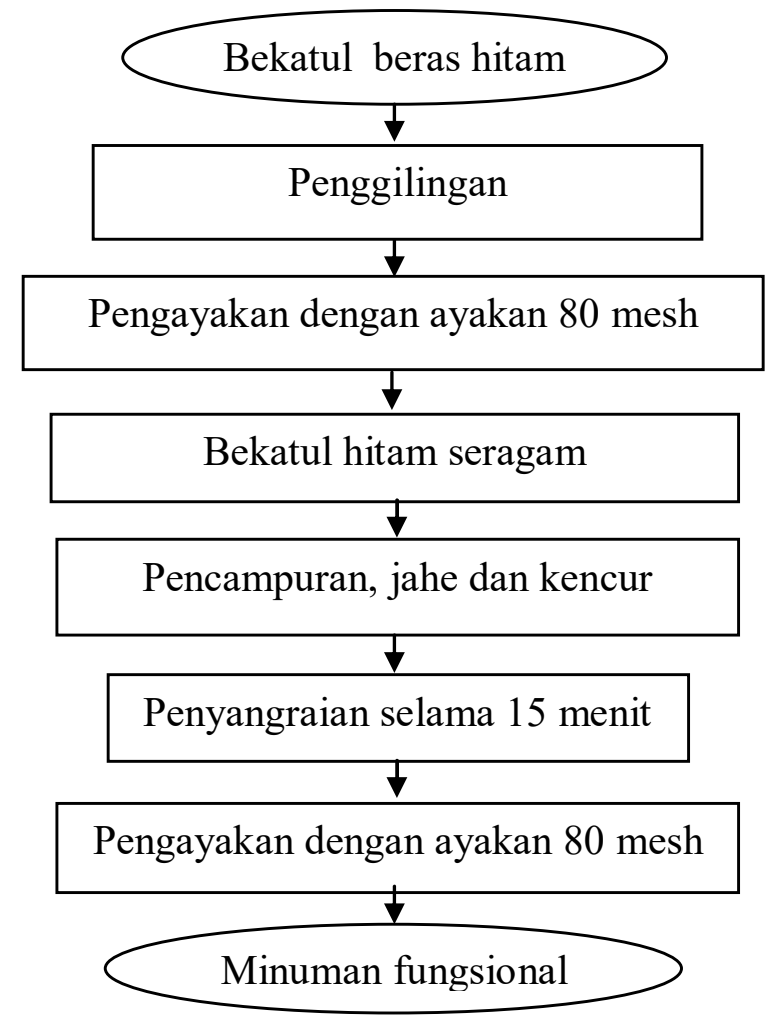

Gambar 1. Tahapan Pembuatan Minuman Fungsional Bekatul Beras Hitam

Tabel 1. Formulasi minuman:

\begin{tabular}{lccc}
\hline Jenis Bekatul & \multicolumn{3}{c}{ Perlakuan } \\
\cline { 2 - 4 } & Bekatul & Jahe & Kencur \\
\hline Formula A & 70 & 25 & 5 \\
Formula B & 70 & 20 & 10 \\
Formula C & 70 & 15 & 15 \\
Formula D & 70 & 10 & 20 \\
Formula E & 70 & 5 & 25 \\
\hline
\end{tabular}

Tabel 2. Metode Analisis

\begin{tabular}{cll}
\hline No & Macam Analisis & \multicolumn{1}{c}{ Metode } \\
\hline 1. & Aktivitas & Metode DPPH (Subagio, \\
& Antioksidan & 2001 dalam Susilowati, \\
2010) & Metode pH differential \\
2. & Total & (Giusti dan Worlstad, 2001) \\
& Antosianin & $\begin{array}{l}\text { Metode Follin-ciocalteu } \\
\text { (Senter dkk, 1989 }\end{array}$ \\
3. & Total Fenol & dimodifikasi dengan Metode \\
& & Plumer,1971) \\
4. Sensori & Uji Kesukaan Metode \\
& & Skoring (Kartika dkk, 1988). \\
\hline
\end{tabular}




\section{HASIL DAN PEMBAHASAN}

Penentuan Formula Minuman Fungsional Terbaik

1. Warna

Hasil uji kesukaan-skoring terhadap parameter warna minuman bekatul beras hitam dengan penambahan jahe dan kencur ditunjukkan pada Tabel 3.

Tabel 3. Tingkat Kesukaan terhadap Warna Minuman Fungsional

\begin{tabular}{cl}
\hline $\begin{array}{c}\text { Formula } \\
\text { Bekatul }: \text { Jahe }: \text { Kencur }\end{array}$ & Nilai \\
\hline $70: 25: 5$ & $3,27^{\mathrm{a}}$ \\
$70: 20: 10$ & $3,46^{\mathrm{a}}$ \\
$70: 15: 15$ & $3,38^{\mathrm{a}}$ \\
$70: 10: 20$ & $3,31^{\mathrm{a}}$ \\
$70: 5: 25$ & $3,23^{\mathrm{a}}$ \\
\hline
\end{tabular}

Keterangan: huruf yang berbeda di belakang angka menunjukkan beda nyata pada taraf signifikansi $\alpha 5 \%$.

Dari data hasil uji parameter warna menunjukkan bahwa pada masing-masing formulasi minuman bekatul beras hitam tidak berbeda nyata hal ini disebabkan karena dari kelima sampel menunjukkan warna yang sama yaitu ungu kehitam-hitaman. Zat warna yang terkandung dalam bekatul beras hitam ini adalah antosianin yang berwarna ungu. Sedangankan pada jahe dan kencur zat warna yang terkandung adalah kurkumin yang mempunyai warna kuning, Penambahan jahe dan kencur pada minuman fungsional bekatul beras hitam tidak berpengaruh terhadap warna minuman. Hal ini dikarenakan warna kuning dari jahe dan kencur tersebut bercampuran dengan warna ungu dari bekatul beras hitam yang sangat pekat sehingga minuman fungsional bekatul beras hitam terbentuk ungu kehitaman.

Menurut Ridiah (2010), pada beras hitam, aleuron dan endospermia memproduksi antosianin dengan intensitas tinggi sehingga warna beras menjadi ungu pekat mendekati hitam. Antosianin merupakan salah satu jenis komponen flavonoid yang paling sering dijumpai di alam. Komponen flavonoid sendiri merupakan subkelompok dari komponen fenolik. Pigmen ini bersifat larut air dan memberikan berbagai macam warna pada tumbuhan, seperti biru, ungu, violet, magenta, merah, dan jingga (Elbe and Schwartz, 1996) dalam Shinta (2008).

\section{Aroma}

Hasil uji kesukaan-skoring terhadap parameter aroma minuman bekatul beras hitam dengan penambahan jahe dan kencur ditunjukkan pada Tabel 4.

Tabel 4. Tingkat Kesukaan terhadap Aroma Minuman Fungsional

\begin{tabular}{cl}
\hline $\begin{array}{c}\text { Formula } \\
\text { Bekatul }: \text { Jahe }: \text { Kencur }\end{array}$ & Nilai \\
\hline $70: 25: 5$ & $3,50^{\mathrm{b}}$ \\
$70: 20: 10$ & $3,46^{\mathrm{b}}$ \\
$70: 15: 15$ & $3,38^{\mathrm{b}}$ \\
$70: 10: 20$ & $2,96^{\mathrm{a}}$ \\
$70: 5: 25$ & $2,92^{\mathrm{a}}$ \\
\hline
\end{tabular}

Keterangan: huruf yang berbeda di belakang angka menunjukkan beda nyata pada taraf signifikansi $\alpha 5 \%$.

Berdasarkan Tabel 4 diketahui bahwa nilai kesukaan panelis terhadap aroma minuman fungsional bekatul beras hitam berkisar antara 2,92-3,50. Hal ini menunjukkan bahwa penilaian panelis terhadap aroma minuman fungsional bekatul beras hitam yang dihasilkan adalah tidak suka sampai netral. Dari hasil uji sensori terhadap parameter aroma menunjukkan bahwa pada formulasi 70:25:5 memiliki nilai rata-rata tertinggi yaitu sebesar 3,50 (netral) dan pada formulasi 70:5:25 memiliki nilai rata-rata terendah yaitu sebesar 2,92 (tidak suka cenderung netral).

Menurut Astawan (2008), aroma langu disebabkan adanya aktivitas enzim lipoksigenase yang menghidrolisis asam lemak-asam lemak tak jenuh menjadi senyawa-senyawa mudah menguap seperti aldehid dan keton. Oleh karena itu penambahan jahe dan kencur diharapkan dapat mengurangi aroma langu dari bekatul tersebut. Penambahan jahe dan kencur dalam minuman, karena jahe dan kencur memiliki senyawa 
volatil yang menyebabkan aroma pada minuman ini, sehingga aroma langu dari bekatul dapat dikurangi. Komponen utama pada minyak atsiri jahe yang menyebabkan bau harum yaitu zingiberen dan zingiberol (Herman, 1985). Dan komponen utama pada kencur yang berperan sebagai aroma yaitu ester-ester dari asam sinamat (Burkill, 1935).

\section{Rasa}

Hasil uji kesukaan-skoring terhadap parameter rasa minuman ringan bekatul beras hitam dengan penambahan jahe dan kencur ditunjukkan pada Tabel 5.

Tabel 5. Tingkat Kesukaan terhadap Rasa Minuman Fungsional

\begin{tabular}{cl}
\hline $\begin{array}{c}\text { Formula } \\
\text { Bekatul }: \text { Jahe }: \text { Kencur }\end{array}$ & Nilai \\
\hline $70: 25: 5$ & $2,96^{\mathrm{a}}$ \\
$70: 20: 10$ & $3,58^{\mathrm{b}}$ \\
$70: 15: 15$ & $3,62^{\mathrm{b}}$ \\
$70: 10: 20$ & $3,04^{\mathrm{a}}$ \\
$70: 5: 25$ & $2,81^{\mathrm{a}}$ \\
\hline
\end{tabular}

Keterangan: huruf yang berbeda di belakang angka menunjukkan beda nyata pada taraf signifikansi $\alpha 5 \%$.

Berdasarkan Tabel 5 dapat diketahui bahwa nilai kesukaan panelis terhadap rasa minuman ringan fungsional bekatul beras hitam berkisar antara 2,81-3,62 (tidak suka cenderung suka sampai netral cenderung suka). Hal ini menunjukkan bahwa penilaian panelis terhadap rasa minuman ringan fungsional bekatul beras hitam yang dihasilkan adalah tidak suka cenderung netral sampai netral cenderung suka. Dari hasil uji sensoris terhadap parameter rasa menunjukan bahwa pada formulasi 70:15:15 memiliki nilai ratarata tertinggi yaitu 3,62 (netral cenderung suka). Namun tidak berbeda nyata terhadap formulasi 70:20:10 dengan nilai rata-rata 3,58 (netral cenderung suka). Pada formulasi 70:5:25 memilki nilai rata-rata terendah yaitu 2,81 (tidak suka cenderung netral). Hal ini dikarenakan rasa pada minuman bekatul beras hitam ini sesuai dengan lidah panelis. Pada minuman bekatul beras hitam ini memiliki rasa pedas. Rasa pahit dari bekatul dan kencur dapat tertutupi oleh rasa pedas yang dihasilkan oleh jahe.

Menurut Farrel (1990), sifat khas pedas jahe berasal dari jahe berasal dari atribut senyawa kimia jahe seperti zingeron, shogaol, dan gingerol. Sedangkan senyawa flavor dari minyak atsiri seperti sineol, borneol, geraniol, linalool, dan farmesen yang memberikan aroma khas pada jahe. Komponen utama yang memberikan rasa pedas jahe adalah gingerol dan shagaol (Ravindran, 2005).

Penilaian, panelis lebih menyukai formula minuman 70:15:15, hal ini dikarenakan panelis menyukai perpaduan rasa yang seimbang antara jahe + kencur.

\section{Keseluruhan (Overall)}

Hasil uji kesukaan-skoring terhadap keseluruhan minuman bekatul beras hitam dengan penambahan jahe dan kencur ditunjukkan pada Tabel 6.

Tingkat kesukaan secara keseluruhan dari kelima sampel menunjukan bahwa minuman formula 70:20:10 memiliki nilai rata-rata tertinggi yaitu 3,62 (netral cenderung suka), tidak berbeda nyata dengan formula 70:15:15 yaitu 3,50 (netral). Hal tersebut menunjukkan bahwa minuman fungsional bekatul beras hitam dengan formulasi 70:20:10 dan 70:15:15 disukai oleh panelis, karena dilihat dari tingkat kesukaan warna, aroma dan rasa juga paling unggul.

Berdasarkan uraian tersebut dapat diketahui bahwa minuman fungsional bekatul beras hitam dengan penambahan jahe dan kencur diterima oleh panelis.

\section{Analisis Kapasitas Antioksidan}

Pengukuran kapasitas antioksidan yang terdiri dari total fenol, total antosianin, dan aktivitas antioksidan.

\section{Analisis Kadar Total Fenol}

Hasil pengukuran kadar total fenol ditunjukkan pada Tabel 7. 
Tabel 6. Tingkat Kesukaan terhadap Keseluruhan Minuman Fungsional Bekatul

\begin{tabular}{ccccc}
\hline $\begin{array}{c}\text { Formula } \\
\text { Bekatul : Jahe }: \text { Kencur }\end{array}$ & Warna & Aroma & Rasa & Keseluruhan \\
\hline $70: 25: 5$ & $3,27^{\mathrm{a}}$ & $3,50^{\mathrm{b}}$ & $2,96^{\mathrm{a}}$ & $3,12^{\mathrm{a}}$ \\
$70: 20: 10$ & $3,46^{\mathrm{a}}$ & $3,46^{\mathrm{b}}$ & $3,58^{\mathrm{b}}$ & $3,62^{\mathrm{b}}$ \\
$70: 15: 15$ & $3,38^{\mathrm{a}}$ & $3,38^{\mathrm{b}}$ & $3,62^{\mathrm{b}}$ & $3,50^{\mathrm{b}}$ \\
$70: 10: 20$ & $3,31^{\mathrm{a}}$ & $2,96^{\mathrm{a}}$ & $3,04^{\mathrm{a}}$ & $3,19^{\mathrm{a}}$ \\
$70: 5: 25$ & $3,23^{\mathrm{a}}$ & $2,92^{\mathrm{a}}$ & $2,81^{\mathrm{a}}$ & $2,96^{\mathrm{a}}$ \\
\hline
\end{tabular}

Keterangan: huruf yang berbeda di belakang angka menunjukkan beda nyata pada taraf signifikansi $\alpha 5 \%$.

Tabel 7. Kadar Total Fenol Minuman Fungsional Bekatul Beras Hitam

\begin{tabular}{cc}
\hline $\begin{array}{c}\text { Sampel } \\
\text { Bekatul : Jahe : Kencur }\end{array}$ & $\begin{array}{c}\text { Kadar Total } \\
\text { Fenol } \\
(\mathrm{mg} / 100 \mathrm{ml})\end{array}$ \\
\hline Kontrol $(100: 0: 0)$ & $506,24^{\mathrm{b}}$ \\
$70: 20: 10$ & $654,18^{\mathrm{a}}$ \\
$70: 15: 15$ & $705,99^{\mathrm{a}}$ \\
\hline
\end{tabular}

Keterangan: huruf yang berbeda di belakang angka menunjukkan beda nyata pada taraf signifikansi $\alpha 5 \%$.

Berdasarkan Tabel 7 diketahui bahwa kadar total fenol kontrol bekatul dengan formula 100:0:0 (Bekatul : Jahe : Kencur) berbeda nyata dengan formula 70:20:10 dan formula 70:15:15. Pada minuman penambahan jahe dan kencur memiliki kadar total fenol yang tidak berbeda nyata. Pada formula 70:20:10 memiliki kadar total fenol sebesar $654,18 \mathrm{mg} / 100 \mathrm{ml}$, dan pada formula 70:15:15 memiliki kadar total fenol sebesar 705,99 mg/100ml, yang berperan dalam menentukan total fenol adalah karena adanya ekstrak jahe dan kencur. Senyawa yang terkandung dalam Zingiberaceae diantaranya adalah senyawa fenolik seperti gingerol,shogaol, gingeron (Ravindran et al.,2005),

Senyawa polifenol khususnya komponen gingerol diduga lebih stabil terhadap perubahan suhu selama proses pengolahan maupun penyimpanan dibandingkan dengan senyawa fenol dari golongan antosianin yang ada dalam bekatul beras hitam.

\section{Kadar Total Antosianin}

Hasil pengukuran kadar total antosianin ditunjukkan pada Tabel 8.
Tabel 8. Kadar Total Antosianin Minuman Fungsional Bekatul Beras Hitam

\begin{tabular}{cc}
\hline $\begin{array}{c}\text { Sampel } \\
\text { Bekatul : Jahe : Kencur }\end{array}$ & $\begin{array}{c}\text { Kadar Total } \\
\text { Antosianin } \\
(\mathrm{mg} / \mathrm{L})\end{array}$ \\
\hline Kontrol (100:0:0) & $169,54^{\mathrm{b}}$ \\
$70: 20: 10$ & $118,23^{\mathrm{a}}$ \\
$70: 15: 15$ & $133,97^{\mathrm{a}}$ \\
\hline
\end{tabular}

Keterangan: huruf yang berbeda di belakang angka menunjukkan beda nyata pada taraf signifikansi $\alpha 5 \%$.

Berdasarkan Tabel 8 diketahui bahwa kadar total antosianin minuman dengan formula 70:15:15 sebesar 133,97 $\mathrm{mg} / 100 \mathrm{ml}$ sedangkan kadar total antosianin minuman dengan formula 70:20:10 sebesar 118,23 mg/100 ml. Berdasarkan hasil analisa nilai kadar total antosianin minuman menunjukkan tidak berbeda nyata antara minuman dengan formula 70:15:15 dan minuman dengan formula 70:20:10. Namun berbeda nyata dengan kontrol (100:0:0).

Kadar total antosianin pada minuman dengan formula 70:20:10 lebih kecil dibandingkan dengan formula 70:15:15, karena diduga dengan adanya vitamin $\mathrm{C}$ pada jahe menyebabkan kestabilan antosianin berkurang. Menurut Ravindra et al., (2005) dalam Widiyanti (2009), kandungan Vitamin C pada jahe yaitu sebesar $44 \%$ per berat kering. Pada formula 70:20:10 kadar antosianinnya lebih sedikit karena perbandingan jahenya lebih besar, sehinnga kestabilan antosianinnya berkurang dibandingkan dengan formula 70:15:15 yang kadar jahenya lebih sedikit. Menurut Poei-Langston dan 
Wrolstad, 1981; Marti et al., 2002 dalam Rein, 2005): Kerusakan antosianin dipercepat oleh kehadiran asam askorbat Diterangkan lebih lanjut bahwa: Pembentukan hidrogen peroksida dari oksidasi asam askorbat juga dapat mempengaruhi stabilitas antosianin. Oleh karena itu dengan adanya kandungan vitamin $\mathrm{C}$ yang tinggi menyebabkan kestabilan antosianin berkurang. Juga diduga pemanasan selama proses pembutan minuman juga dapat menurunkan kadar antosianin karena antosianin peka terhadap panas.

\section{Aktivitas Antioksidan}

Hasil pengukuran aktivitas antioksidan pada minuman fungsional bekatul beras hitam dengan penambahan jahe dan kencur ditunjukkan pada Tabel 9.

Tabel 9. Aktivitas Antioksidan Minuman Fungsional Bekatul Beras Hitam

\begin{tabular}{cc}
\hline Sampel & Aktivitas \\
Bekatul : Jahe : Kencur & $\begin{array}{c}\text { Antioksidan } \\
(\%)\end{array}$ \\
\hline Kontrol $(100: 0: 0)$ & $36,01^{\mathrm{a}}$ \\
$70: 20: 10$ & $41,81^{\mathrm{b}}$ \\
$70: 15: 15$ & $54,36^{\mathrm{c}}$ \\
\hline
\end{tabular}

Keterangan: huruf yang berbeda di belakang angka menunjukkan beda nyata pada taraf signifikansi $\alpha 5 \%$.

Berdasarkan Tabel 9. diketahui bahwa aktivitas antioksidan pada kontrol bekatul 100\% tanpa penambahan sebesar $36,01 \%$, pada minuman bekatul dengan formula 70:15:15 sebesar 41,81 \%, sedangkan aktivitas antioksidan pada minuman formula 70:20:10 sebesar $54,36 \%$. Berdasarkan data hasil (ANOVA) dapat diketahui bahwa kombinasi formulasi dalam pembuatan minuman seperti yang ada di Tabel 9 memberikan pengaruh yang beda nyata terhadap aktivitas antioksidan.

Aktivitas antioksidan pada minuman fungsional bekatul banyak dipengaruhi oleh beberapa hal karena bekatul mengandung tokoferol dan tokotrienol yang berfungsi sebagai antioksidan yang bermanfaat dalam berbagai pencegahan penyakit termasuk penuaan dini. Menurut Siebenmorgen T, (2004) menunjukkan bahwa antioksidan bekatul terutama vitamin E dan oryzanol, serta lemak tidak jenuhnya yang mampu sebagai penurun kolesterol. Kemampuan antioksidatif banyak disumbang dari senyawa fenol, yaitu antioksidan yang efektif dan banyak digunakan dalam bahan pangan. Di samping senyawa fenol, rempah-rempah juga mengandung senyawa antioksidan lain berupa asamasam organik. Di dalam bekatul yang lebih berperan dalam aktivitas antioksidan yaitu pigmen antosianin yang termasuk dalam golongan flavonoid sebagai salah satu senyawa fenol. Vitamin E yang terkandung dalam bekatul beras hitam juga memiliki aktivitas antioksidan, walaupun efektivitas vitamin E tidak sebesar senyawa polifenol. Seperti yang dijelaskan Silalahi (2002), kemampuan polifenol menangkap radikal bebas, 100 kali lebih efektif dibandingkan vitamin C.

Seperti pada Tabel 7 bahwa minuman fungsional bekatul beras hitam formula (bekatul:jahe:kencur) 70:15:15 dan formula 70:20:10 lebih besar aktivitas antioksidannya karena senyawa polifenol di dalamnya lebih besar dibandingkan kontrol minuman bekatul beras hitam. Jadi aktivitas antioksidan dalam formula 70:15:15 dan 70:20:10 sangat ditentukan oleh kadar total fenol yang terkandung.

Diduga aktivitas penakapan radikal bebas dalam minuman fungsional bekatul beras hitam lebih banyak dikontribusi oleh senyawa fenolik terutama zingiberen. Seperti yang telah dijelaskan sebelumnya bahwa senyawa polifenol khususnya komponen zingiberen lebih stabil terhadap pemanasan pada suhu yang tinggi dibandingkan dengan senyawa fenol dari golongan antosianin yang ada dalam bekatul beras hitam. Proses pemanasan merupakan salah satu faktor yang diduga menyebabkan kestabilan antosianin berkurang, berbanding lurus dengan 
besar aktivitas penangkapan radikal bebas.

\section{KESIMPULAN DAN SARAN}

\section{Kesimpulan}

Berdasarkan penelitian yang telah dilakukan, dapat diambil kesimpulan yaitu dari karakteristik sensori dan kapasitas antioksidan minuman ringan fungsional bekatul beras hitam dengan penambahan jahe (Zingiber officinale) dan kencur (Kamferia galangal 1) terbaik adalah minuman dengan formula 70:15:15 (bekatul : jahe : kencur). Dengan kadar total fenol sebesar 705,99 $\mathrm{mg} / 100 \mathrm{ml}$, kadar total antosianin 133,97 $\mathrm{mg} / 100 \mathrm{ml}$, dan aktivitas antioksidan 54,36\%.

\section{Saran}

Berdasarkan penelitian yang telah dilakukan, saran yang dapat disampaikan yaitu perlu dilakukan penelitian lebih lanjut mengenai metode pembuatan minuman ringan fungsional sehingga menghasilkan minuman yang lebih baik kualitasnya ditinjau dari kandungan nutrisi, dan sifat fungsional (vitamin E, serat pangan, asam ferulat, $\gamma$ oryzanol) dan kualitas sensorinya.

\section{DAFTAR PUSTAKA}

Auliana, Rizqie, 2011. Manfaat Bekatul dan Kandungan Gizinya. Dalam Kegiatan Dharma Wanita, FT UNY. Yogyakarta.

Astawan, M. dan Andi Early F. 2010. Potensi Dedak dan Bekatul Beras Sebagai Ingridient Pangan dan Produk Pangan Fungsional. Artikel Pangan. Vol. 19 No.1.

Champagne, E. T. 1994. Rice Chemistry and Technology. American Association of Cereal Chemists. Inc, St. Paul.

Kiswanto, Y. 2008. Pengembangan Produk Minuman Instan Dari Temulawak Dengan Teknik Kokristalisasi. Fakultas Teknologi Pertanian INTAN Yogyakarta. Yogyakarta

Rostiana, Otih dan. Dedi Soleh Effendi. 2007. Teknologi Unggulan Kencur Perbenihan dan Budidaya Pendukung Varietas Unggul. Pusat Penelitian dan
Pengembangan Perkebunan. ISBN : 978979-8451-61-4. Bogor.

Sutarno H, Hadad EA, Brink M. 1999. Zingiber officinale Roscoe. Di dalam: C.C. de Guzman dan J.S. Siemonsma, Editor. Spices Plant Resources of SouthEast Asia. Bogor PROSEA Foundation 13: 238-244.

Silalahi, J. 2006. Makanan Fungsional. Penerbit Kanisius. Yogyakarta.

Wijaya, Hanny. 2002. Pangan Fungsional Dan Kontribusinya Bagi Kesehatan. Makalah Seminar Online Kharisma ke-2. Diakses 13 Desember 2010. 